ISSN 1112-9867

http://www.jfas.info

\title{
ENVIRONMENTAL ARCHITECTURE: THE ROLE OF SUSTAINABLE STRUCTURES IN FUTURISTIC BUILDINGS
}

\author{
O. Rahaei, S. Derakhshan and N. Shirgir
}

Shahid Rajaei Teacher Training University, Department of Architecture, Tehran, Iran

Published online: 15 May 2016

\begin{abstract}
At the beginning of the 21 st century the term of "sustainable architecture" became the focus of many architectural debates. To approach sustainability, it is important to postpone the "end of life" of buildings. In this regard the structures of buildings play a significant role and the term of "sustainable structure" is therefore introduced. This paper is going to explain the term of "sustainable structure" in some case studies, and explores strategies toward obtaining sustainable structures. This article which is derived from an interpretive-historical research has a systematic methodology and the analysis is implemented in a deskwork process. The construction strategies in the fields of "Efficacy", "maintenance" and "end of life" issues are considered. The considerations are concentrated on the structural members and materials in those buildings. Finally the paper proposes some outlines in design of futuristic structures.
\end{abstract}

Keywords: Environmental Architecture, Sustainable Structure, Efficiency, Maintenance.

Author Correspondence, e-mail: o.rahaei@srttu.edu

doi: http://dx.doi.org/10.4314/jfas.v8i3s.241

\section{INTRODUCTION}

With approximately 6.7 billion people on Earth now and a projected 9 billion by mid-century of 21, finding some new ways of reducing consumption is inevitable if avoiding dramatic environmental degradation and the potential of global ecosystem collapse is important for humanity. Building industry is known as a major consumer of energy and material resources 
in the world and it was said that construction is the second industry in the world after agriculture [1]. Buildings have many impacts on the environment; during design processes, construction, and also through operation. Construction industry consumes a large amount of all energy used in the world, driven by the considerable energy used and waste generated in making building products from the extraction, processing and transportation of raw materials. Construction waste generates 136 million tons annually between demolition, renovation, and maintenance also [2].

Nowadays the technological innovations in communications, computer's systems, electronics, and the automobile industries have surrounded the mankind (Fig. 1). however the most important purchase order of the people in whole of their life, buying house, is not developed and it's still done like past: the home that will define all life of human in next 40 or more years of his life, is not oriented toward the future. In the other word it would be defunctive so sooner than the past in contrast with the position of increasingly development of sciences and technologies. In the field of materials, although each has environmental advantages and disadvantages, producing and transporting them consumes a lot of nonrenewable resources and entails many environmental impacts. However energy intensive materials like steel and concrete can be used more efficiently and alternate materials should be explored specially in structural elements of buildings [3]. The structures of buildings have major role in consumptions of resources and result many environmental impacts. So the considerations of this paper are devoted to the structure's environmental impacts and will result in definition of "sustainable structure".

\section{SUSTAINABLE DEVELOPMENT}

"Sustainability" and in turn "sustainable development" are terms that mean different things to different people, making it difficult to provide a single definition. The original definition (and the one still most widely used) of sustainable development was made in the Bruntland Report (1987) which defined it as: "Development that meets the needs of the present without compromising the ability of future generations to meet their own needs" [5].

Sustainable development is all about ensuring a better quality of life for everyone, now and for generations to come. This can be achieved through the three strands of social equity which recognizes the needs of everyone, maintenance of stable levels of economic growth and employment, and using natural resources prudently, whilst protecting, and if possible enhancing, the environment [6]. This can be shown diagrammatically as Fig. 2. 
Sustainability was first raised officially during the Earth Summit in 1992, bringing Agenda 21 to the forefront. Since then, institutions and businesses alike have adopted various strategies to lower their 'carbon output' and reduce their global footprint. In 1997 the issue of sustainability was once again raised in the form of the Kyoto Accord. The object of this new protocol was the "stabilization of greenhouse gas concentrations in the atmosphere at a level that would prevent dangerous anthropologic interference with the climate system". In other words this means reducing our carbon footprint to a level which would prevent dangerous human interference with the climate [7].

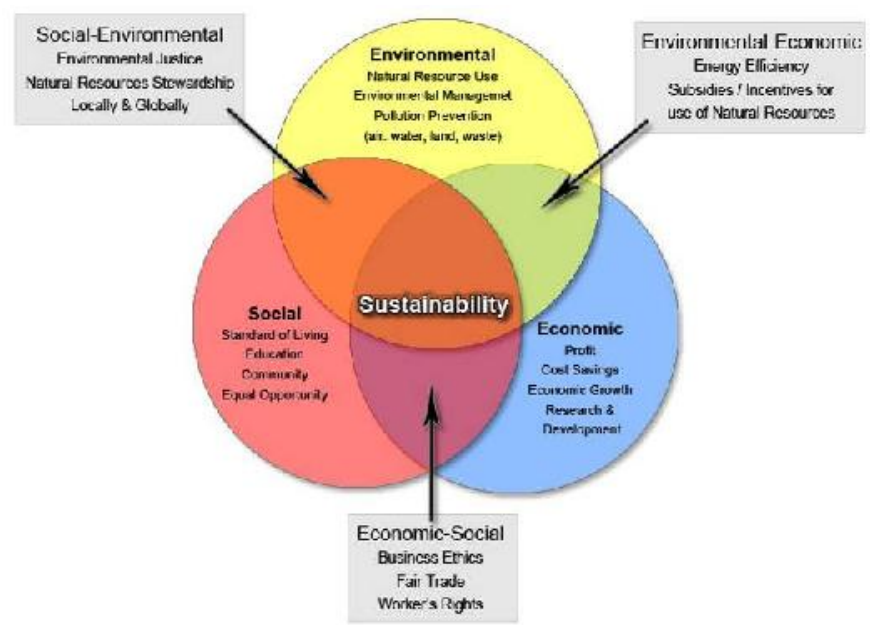

Fig.1. The three spheres of sustainability [8]

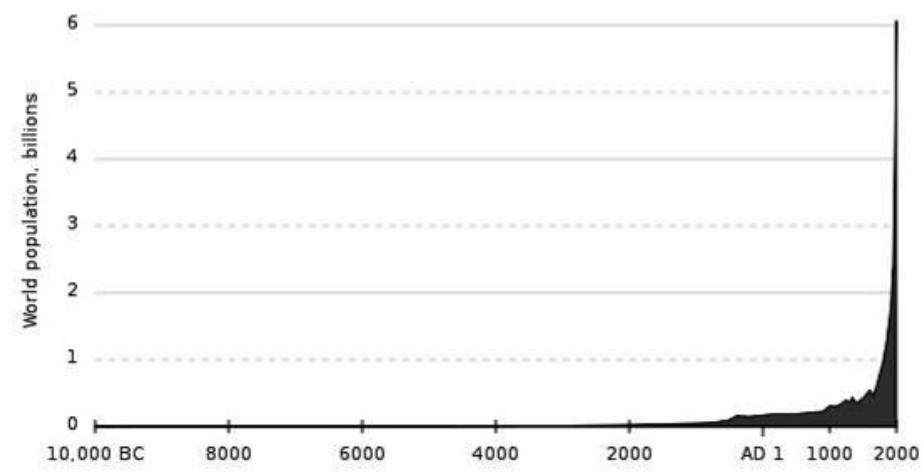

Fig.2. The state of the world's populations from 10000 BC till 2000AD [9] 


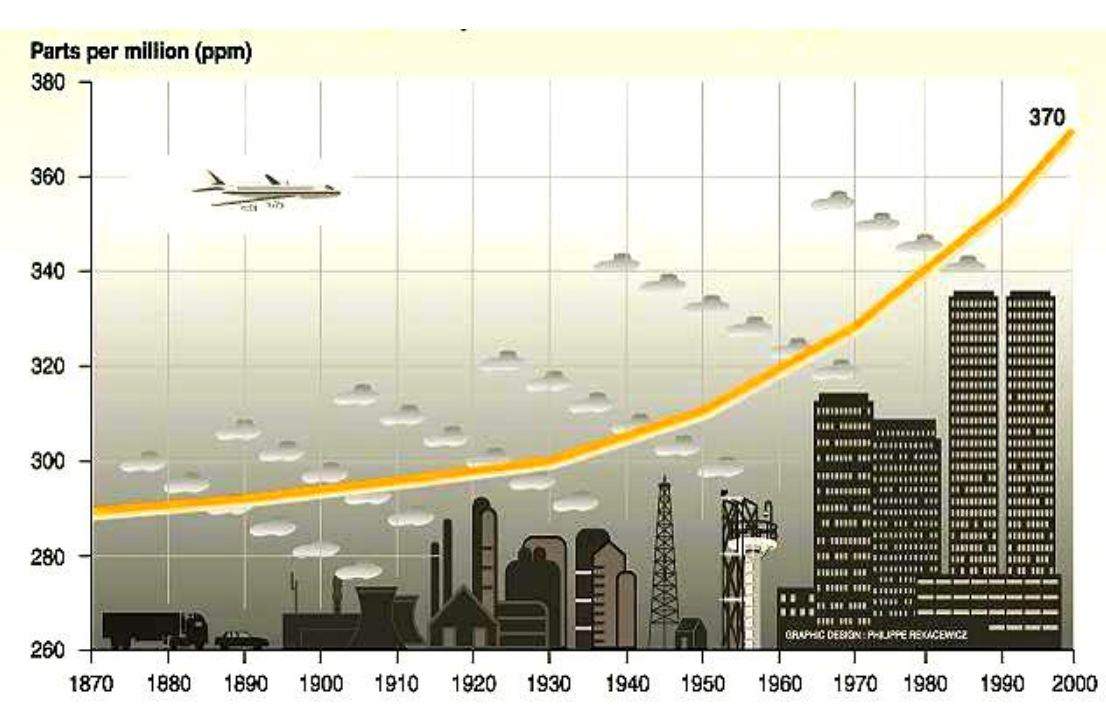

Fig.3. Global carbon dioxide emissions from human activities, 1870-2000 [10]

An ideal plan for sustainability would benefit the environment, improve the lives of humans, and make money at the same time [11]. Whilst sustainability has been defined as a goal to be reached by working equally towards environment, society, and economy, the Fig. 2 is illustrating the state of increasingly growth of world's population [12] and the global carbon dioxide emissions from human activities is shown diagrammatically as Fig. 3 [13]: the diagrams illustrate a critical circumstance. Meanwhile the construction industry has a major role in environmental impacts and it is necessary to minimize all its adverse impacts and to act in a sustainably responsible manner [14].

\section{ORIGINS OF ENGINEERING IN ARCHITECTURE}

Vitruvius' de Architectura (c 1st century AD) records almost all that is known from antiquity of technological design, and historians of engineering customarily acknowledge Vitruvius as the first writer in their field. In Byzantium, the architects of S. Sophia (6th century AD) were Anthemius, a leading mathematician of his age, and Isodorus who wrote a commentary on the works of Archimedes. They preserved the Hellenic mechanical science. The pristine audacity of Renaissance man, confidently determined to put the entire universe under the sway of human reason, is epitomized in the work of Leonardo da Vinci - painter, sculptor, musician, poet, scientist, and inventor: designer of everything from fortifications to birds. He, like Vitruvius, is never absent from histories of architecture and engineering [15].

To his near-contemporary, the architect Alberti, whom is owed the first great scientific treaties of the age, his mature masterpiece being the 10 books de re Aedificatoria. As did Vitruvius, he 
reviews the entire technology of his time and tries to bring the whole within the scope of scientific principle. His definition of the architect as one “... who, by sure and wonderful art and method, is able ... to devise, and, ... to complete all those works which, by the movement of great weights, and the conjunction and amassment of bodies, can, with the greatest beauty, be adapted to the use of mankind... [16]" compares strikingly with the purpose of civil engineering described by Thomas Tredgold in 1828 as “... the art of directing the great sources of powers in nature for the use and convenience of man..." [17]

For some time yet, architecture was able to retain its traditional interest in technology. Palladio, writing in the mid-16th century, although no longer Vitruvian in his range, includes an excellent exposition of trussed bridges among his palaces, temples and piazzas. When after 1600, Stevinius and Galileo had laid a sound foundation for the whole subsequent development of modern experimental science architects like Christopher Wren and Robert Hooke (whose celebrated law is still a corner-stone of structural theory) were among its first devotees [18].

\section{FOUNDATIONS OF MODRNN TECHNOLOGIES IN ARCHITECTURE}

With Wren and Hooke at meetings of the newly-created Royal Society sat Newton, the scientist and mathematician whose theories and mathematical procedures were to prove an adequate basis for the whole subsequent development of modern technology. Also in the late 17th century world of commerce and manufacture, there were rapidly growing those tendencies which within a century were to see architecture established revolutionary [19].

The change was to come only after the engineers began to perfect for their use the great new constructional material of modern times: wrought iron and its derivative, structural steel. Within 50 years of its introduction into fire-proof mill construction, engineers were confidently using the new material to roof great railway station concourses and to span ravines and estuaries. Unlike the traditional architectures, no rule-of-thumb was adequate. For tasks such as these inventive works, a new modern knowledge in the mechanical sciences, and modern structural analyses in design was needed as fundamental components of civil engineering. Thus the new modern sciences affected the traditional architecture strongly. Whit the coming of the steam age, engineers everywhere were quick to use their sciences to give new shapes to masonry viaducts and timber frameworks. It only needed the invention of reinforced concrete, and the widespread introduction of rolled steel after 1880 consolidates the claim of structural engineering to enter the main stream of architecture [20]. 
Today, engineering and architecture confront one another as estranged members of a once-united family. Collaboration is now essential in the many fields they still have in common: structural design, construction technique, environmental science, town planning, the servicing, and engineering equipments of buildings. Maybe somewhere a new breed of architecture/engineer which is capable, across a wide design spectrum could be created. Whatever the outcome of future development, it is necessary for architect to understand something of modern engineering science [21].

As mentioned before, Renaissance and Baroque were the basis of modernism. The fast developing technologies alongside the loose interests of modern people to traditions were lead to the industrial revolution and the steam age. It changed the aspect of traditional humanity in 19th century into modern. In architecture the invention of wrought iron and reinforced concrete was the consequences of modern revolutions. After that there was a chance for civil and mechanical engineers to introduce themselves to the societies and make limitations for traditional architects. By the way the International Style was created and in spite of the advantages, there were many disadvantages for the environment. The disadvantages were so big that lead the International Style to termination. The problems finally result in some important concerns in the centuries.

\subsection{The 19th century design concerns: EFFICIENCY IS IMPORTANT}

The most important thing in 19th century was just utilization [22]. Benefit and efficiency were the objectives of this century at any rate in any way. Outputs, fast developments, machines and so on were the matter of time. In building industry the invention of new materials such as steel and concrete made revolutions in traditional constructions. Incidently while fast developing, a serious problem engaged the minds of modern people: abundant consumptions of energy resources and raw materials. The main reason was the increasingly requirements for fast developing and production more and more with new materials. Similarly in building industry the consumption of nonrenewable resources became routine. Such activities imposed irrecoverable sufferings to the environment and polluted the earth. Anyway new materials, such as wrought iron and steel, lead to greater concern for efficiency [23]. (Fig. 5)

\subsection{The 20th century design concerns: MAINTENANCE IS IMPORTANT}

The most important concern in 20th century was maintenance problems of costly constructed buildings in the world [24]. The buildings designed and constructed laboriously were not 
responsible to the future developments. They should encounter many changes in their capacity or application and because of inflexibility in the structures, they were condemned to demolition. The constructed buildings in fast developing cities needed a long lifetime also. So the initiative design for buildings is important and it is necessary to design a general program for maintenance matters of building and specially the structures in whole lifetime. So the initial design is important, though the design for maintenance throughout operating life have to be done. (Fig. 6)

\subsection{The 21st century design concerns: END OF LIFE IS IMPORTANT}

"End of life" or "the destruction" of building is a very big problem [25]. Return to environmental cycles or reuse in another processes after death is so important for the materials to prevent the diffusion of pollutions on the earth. Indeed waste from the construction industry is a vast consumer of natural resources on a global scale. It is necessary to design a program for dead time or destruction of buildings. (Fig. 5)

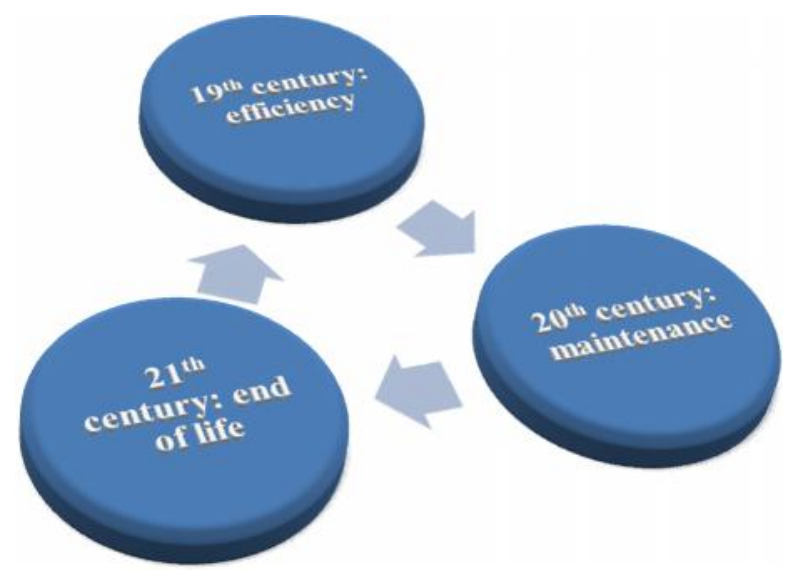

Fig.4. The important concerns of the centuries (authors)

\section{CASE STUDIES}

World statistics illustrate that up to $24 \%$ of solid landfill waste is generated by the construction industry and up to $95 \%$ of construction waste is recyclable [26]. The designs of yesterday are the problems of today and considering them could be useful for future designs. Nevertheless the case studies can illustrate successful and unsuccessful designs and studying the solutions for future can be useful. Here are some futuristic case studies: 


\subsection{Williamsburg Bridge}

The bridge, located in Manhattan, was opened in 1903 as longest span in the world. It was designed with the elastic theory of suspension bridge design, which did not account for the stiffening effect of a cable. Anyway Williamsburg Bridge was boasted to be the "strongest" suspension bridge and Carried traffic and trains throughout the 20th century. However the maintenance was neglected for decades: no maintenance program was planned in design processes. In 1988 the poor condition of the bridge became an emergency and the decays were as the following:

- Main cables were corroded badly because the members were not galvanized at the time of construction.

- Pin joints in the main trusses were corroded. (unpredicted proper maintenance plans)

- The girders were rusted.

Williamsburg Bridge is ranked as the most structurally deficient bridge in the USA carrying more than 50,000 cars per day. It was a vital link to Manhattan and could not be taken out of service. Besides, the property for new approach spans was too expensive and the contractors had to use the same site. So the bridge was condemned to survive at least 100 years more, while the rehabilitating operations cost approximately $\$ 1$ billion more than a new bridge [27].

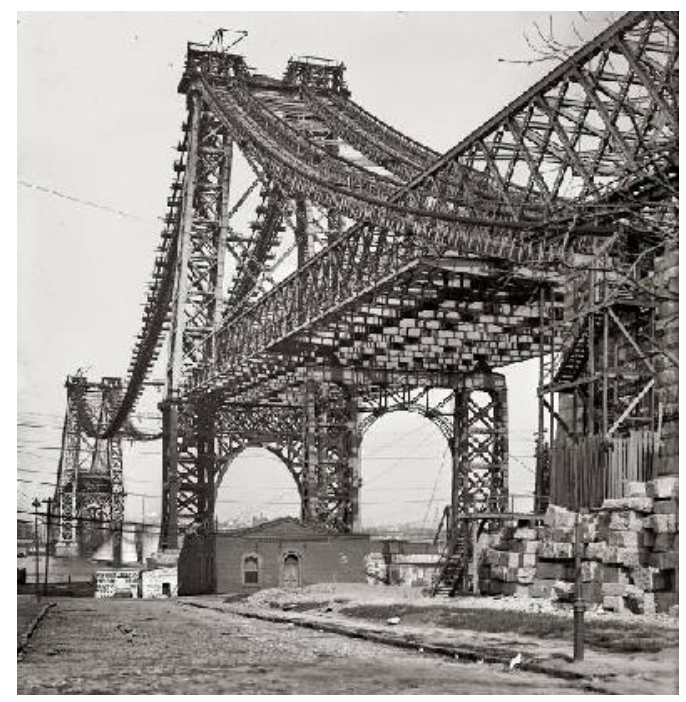

Fig.5. Williamsburg Bridge, 1924. In 1988 the poor condition of the bridge became an emergency [28]

The technical problems were using new cables, new girders, new roadways, new bearings, 
new paint, and so on while the bridge is in charge and exchanging them whit the olds. One strand bundle at a time using the temporary frameworks and columns was needed to replace main cables. Lightweight orthotropic steel deck placed at night was applied to replace deck while traffic flows. The contractors covered large areas with plastic to protect river and traffic from lead paint on the bridge. Finally the bridge was rebuilt. So it is necessary to develop a maintenance plan for any structures, design components which are accessible and replaceable, and avoid toxic materials which are hazardous for future maintenance operations [29].

\subsection{Esfahan's Safavid bridges}

Zayandeh Rud is the greatest river flowing into central plateau of Iran. It flows through the city of Isfahan dividing it into two north south parts. Twelve samples of historic bridges built from Sasanian through Safavid periods stand on it even today. Shahristan Bridge is the oldest of those bridges with a minimum history of one thousand years, which belongs to Sasanian period. There are two other world-famous complex bridges built during the Safavid period: (1) Allahverdi Khan or 33-span bridge (Fig. 7), which is $360 \mathrm{~m}$ long and $14 \mathrm{~m}$ wide, It has 33 spans, and was built by the artful engineers of Isfahan in 1602 A. D.; and (2) Khadlu bridge (in two stories) built during the reign of Shah Abbas II serving both as a bridge and a dam. It is one of the most elaborate combined bridges of the world, $133.5 \mathrm{~m}$ in length and $12 \mathrm{~m}$ in width. It can be changed into a temporary dam by blocking its spans [30].

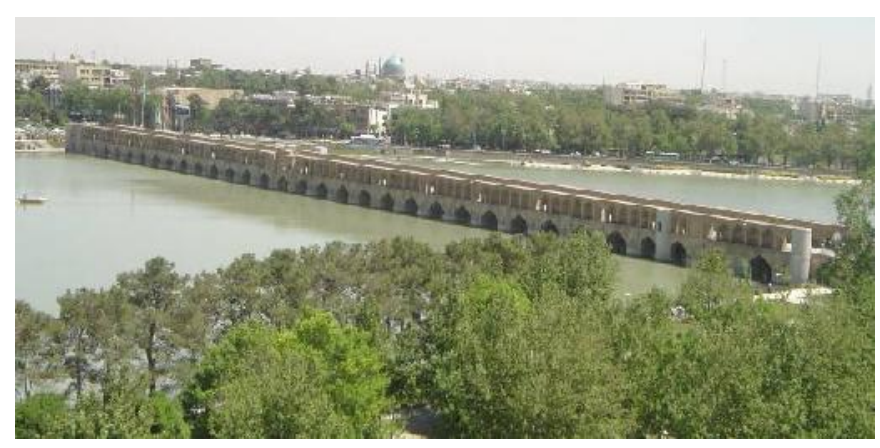

Fig.6. 33 Span Bridge (33 pole), Esfahan. (authors)

In these bridges there is an extreme approach to sustainable structure: very high quality construction, with materials which can be reused in future construction was applied in structures of the bridges. They were built as permanence structures. It is necessary that sustainable structure consider the "end of life" of the structure, as it was in the traditional 
bridges of Esfahan.

\subsection{Pons Fabricius in Rome}

Another example of designing for permanence is Pone Fabricius in rome, $62 \mathrm{BC}$ in Roman tradition (Fig. 8). The structure of the bridge is a kind of sustainable in the form of very high quality construction for permanence [31]. The material can be reused in future structure like the Esfahanian Bridges. The bridge considers the "end of life" of the structure as a masonry bridge. Nevertheless the flexibility of such heavy masonry structures is too weak to be adaptable.

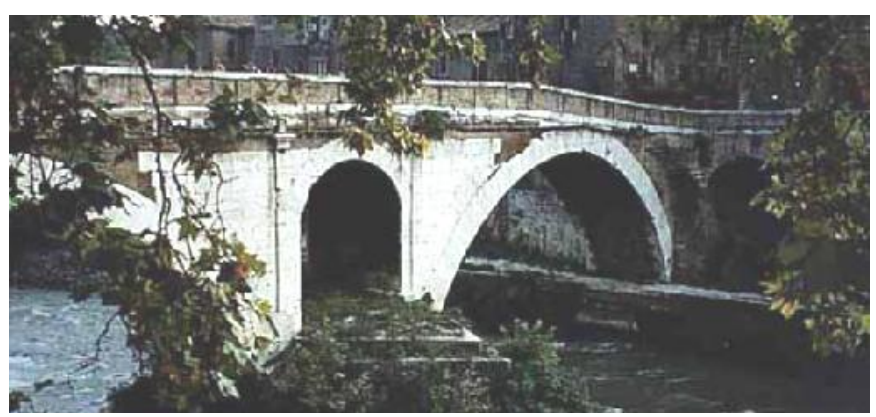

Fig.7. Pons Fabricius in Rome [32]

\subsection{Grass (Rope) structures}

Rope Bridges are some kind of movable structures used for temporary purposes [33]. The Incas used local materials and assemble them to form temporary bridges: the ropes made from local grass or plant fibers were the main members of the structure [34]. However the temporary bridges are local and very cheap, the life time period is very short and the maintenance matters are very important. When a rope bridge became corrupted, old bridges is cut and the new local ropes are installed. Roadway and handrails would be added and the bridge is complete. In this case, the maintenance plan is tied to the community and the native people are architects of their vernacular constructions. Materials are locally available and environmentally sound. So the constructions and their structures are strongly sustainable and the environmental impacts are too low to be a problem. Grass bridges have survived for 500 years tied to the communities [35]. The comparison of suspension bridges and masonry structures was illustrated in table 1 and Fig. 10. 


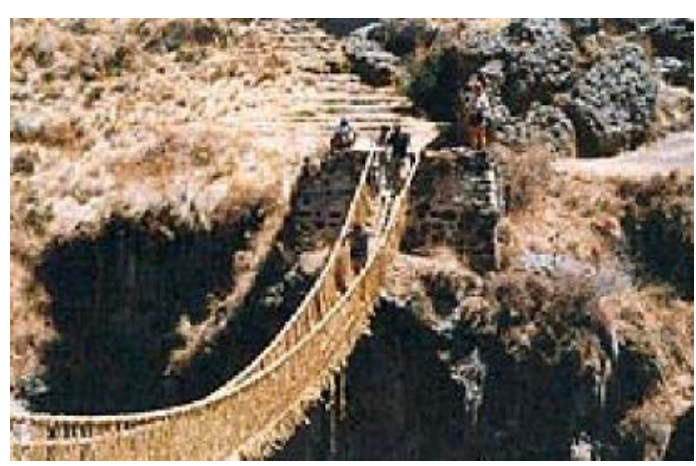

Fig.8. Traditional local rope structures: Inca's suspension bridges [36]

\subsection{Stansted Airport terminal}

In the structure of this building the usage of materials has been planned. Steel tubes can be disassembled and used in another application. They can be replaced easily also, so if a part is corrupted it can be replaced without any demolitions. At the end of life the elements can be recycled without any environmental impacts or can be reused. Modular system for adaptations was anticipated in design [37].

Table 1. Comparison of two structure types that has some sustainable solutions (authors)

\begin{tabular}{cc}
\hline $\begin{array}{c}\text { Suspension Bridges } \\
\text { (traditional people) }\end{array}$ & $\begin{array}{c}\text { Masonry Arc Bridges } \\
\text { (Safavid) }\end{array}$ \\
\hline High stress & Low stress \\
\hline High maintenance & Low maintenance \\
Short lifetime & Long lifetime \\
Low initial cost & High initial cost \\
Renewable material & Renewable material \\
\hline Low load capacity & High load capacity \\
\hline
\end{tabular}




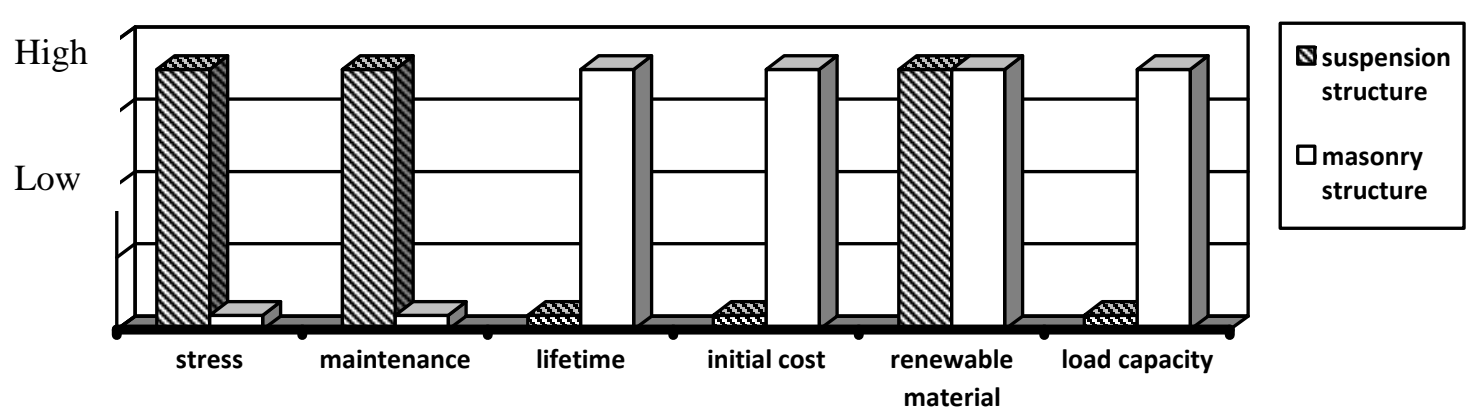

Fig.9. Comparison of two structure types that have solutions illustrated in a chart (authors)

\section{CONCLUSION}

Following the article up to $24 \%$ of solid landfill waste is generated by the construction industry and up to $95 \%$ of construction waste is recyclable. Most of the waste material is clean and unmixed and it is unavoidable that sustainable structures consider the "end of life" matter. Using materials with low environmental impact during their life cycle is necessary both in permanence and temporary structures to approach sustainability. In rope bridges maintenance plan was tied to vernacular community and the materials were local without any environmental impacts. In permanence structures there was no maintenance plan however the materials were local, reusable, and without any environmental impacts. The case studies illustrate that designs of yesterday are the problems of today. This paper introduces the following considerations for choosing structural systems:

- Flexibility of plan

- Adaptability for alternative layouts

- Economical construction

- Utilizing local expertise

- System helping with natural lighting, natural ventilation, and natural performance

In choosing materials the following considerations are necessary:

- Sources of materials

- End of life of the materials

- Contribution of materials with some goals (transparency, thermal, mass and etc.)

Thus in choosing the structural systems and the materials, considering construction, operation, and demolition processes are necessary. To approach more sustainability in structures, building planners should schedule maintenance and efficiency programmes. Therefore "sustainable structures" are executive and open new ways of investing in infrastructures, new 
ways of generating energy and providing a new built environment. Moreover it induces new ways of using durable building materials to consumers. These outlines help approaching sustainable structures:

- Each material has environmental advantages and disadvantages: good design is local

- Recycling or reusing materials to decrease waste

- Considering end of life in the initial design

- History suggests sustainable solutions: rope structures (temporary) and Safavid structures (permanent) can both be sustainable

\section{REFERENCES}

[1] UN, "sustainable development in action" agenda 21, 2009 (www.agenda21france.org)

[2] Building energy data book, 2002 (www.buildingsdatabook.eren.doe.gov)

[3] UN, "sustainable development in action" agenda 21, 2009 (www.agenda21france.org)

[4] News white house, 2009 (www.newswhitehouse.com)

[5] CIRIA, "Sustainable construction procurement. A guide to delivering environmentally $\begin{array}{llll}\text { responsible } \quad \text { (C571), } & \text { CIRIA } & \text { publication, }\end{array}$ (www.ciria.com/complianceplus/sustainability.htm)

[6] World Commission on Environment and Development (WCED), Our Common Future. Oxford: Oxford University Press, 1987.

[7] Hurdsfield, Nathan, 2007. (www.ljmu.ac.uk/sustainability)

[8] CIRIA, "Sustainable construction procurement. A guide to delivering environmentally responsible projects" (C571), CIRIA publication, 2009 (www.ciria.com/complianceplus/sustainability.htm)

[9] Wilson, E. O., “The diversity of life”, W.W. Norton and Company, New York, pp. 424

[10] Hawall, "Mauna Loa Observatory", TP Whorf Scrips, US, California, university of California La Jolla, institute of oceanography (SIO), 1999

[11] UN, "sustainable development in action" agenda 21, 2009 (www.agenda21france.org)

[12] Robert, E., "Human Overpopulation, Poverty and Wildlife Extinction", 2009. (www.naturenorth.com/YOTF/Overpopulation.html)

[13] News white house, 2009 (www.newswhitehouse.com)

[14] CIRIA, "Sustainable construction procurement. A guide to delivering environmentally $\begin{array}{llll}\text { responsible } \quad \text { (C571), } & \text { CIRIA } & \text { publication, }\end{array}$ (www.ciria.com/complianceplus/sustainability.htm) 
[15] Hodgkinson, A., “AJ Handbook of Building Structure”, London: Mackays Ltd, 1983, p. 10

[16] Brookes, A., and Poole, D., "Innovations in Architecture”, London: spon press, 2004.

[17] Hodgkinson, A., “AJ Handbook of Building Structure”, London: Mackays Ltd, 1983, 10

[18] Hodgkinson, A., “AJ Handbook of Building Structure”, London: Mackays Ltd, 1983, p. 11

[19] Gardner, H., “Art through the ages”, 6th edition, edited by Faramarzi, M. Iran: Naghsh Jahan Ltd, 1991, pp. 560-566

[20] Hodgkinson, A., “AJ Handbook of Building Structure”, London: Mackays Ltd, 1983, p. 12

[21] Hodgkinson, A., “AJ Handbook of Building Structure”, London: Mackays Ltd, 1983, p. 14

[22] Rahaei, O., "future structures and sustainable architecture", in: first international conference on structure and architecture, Iran, Tehran. Tehran: Tehran University, 2007

[23] Ochsendorf, J., "Sustainable design". In: International Conference on The role of individuals, New York. New York: Centre for Sustainable Development, 2004.

[24] Rahaei, O., "future structures and sustainable architecture", in: first international conference on structure and architecture, Iran, Tehran. Tehran: Tehran University, 2007

[25] Ochsendorf, J., "Sustainable design". In: International Conference on The role of individuals, New York. New York: Centre for Sustainable Development, 2004.

[26] News white house, 2009 (www.newswhitehouse.com)

[27] The road information program, "The Nations Bridges at 40", 2002 report (www.tripnet.org)

[28] www.shajir.com/post/109163713/zachklein-massive-gorgeous-photo-of

[29] The road information program, "The Nations Bridges at 40", 2002 report (www.tripnet.org)

[30] Hillenbrand, R., "Islamic Architecture”, Edinburgh: Edinburgh University Press, 2000.

[31] Cowan, H. J., “Architectural Structures”, Spottiswood Ballantyne LTD, 1980.

[32] www.rutahsa.com (2009)

[33] www.cenesta.com (2007)

[34] The road information program, "The Nations Bridges at 40", 2002 report (www.tripnet.org)

[35] Cowan, H. J., “Architectural Structures”, Spottiswood Ballantyne LTD, 1980. 
[36] www.rutahsa.com (2009)

[37] Ochsendorf, J. (2004), "Sustainable design". In: International Conference on The role of individuals, New York. New York: Centre for Sustainable Development.

How to cite this article:

Rahaei O., Derakhshan S and Shirgir N. Environmental architecture: the role of sustainable structures in futuristic buildings. J. Fundam. Appl. Sci., 2016, 8(3S), 599-613. 